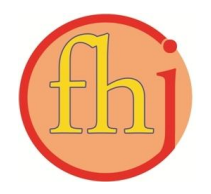

Faletehan Health Journal, 7 (1) (2020) 42-47

www. journal.Ippm-stikesfa.ac.id/ojs/index.php/FHJ

ISSN 2088-673X | e-ISSN 2597-8667

\title{
Hubungan Karakteristik Ibu Yang Memiliki Bayi Usia 0-24 Bulan Dengan Pengetahuan Tentang Pijat Bayi
}

\author{
Nurseha $^{1 *}$, Dewi Komalasari ${ }^{1}$ \\ 1Program Studi Diploma III Kebidanan Universitas Faletehan \\ *Corresponding Author: seha.hendra110807@gmail.com
}

\begin{abstract}
Abstrak
Pijat bayi sebagai bentuk bahasa sentuhan yang memiliki efek positif untuk pertumbuhan dan perkembangan bayi. Pijat bayi dapat meningkatkan kadar enzim penyerapan gastris dan insulin sehingga penyerapan makanan menjadi lebih baik, menyebabkan bayi cepat lapar, lebih sering menyusu dan produksi ASI meningkat. Ibu yang memiliki bayi memerlukan pengetahuan tentang pijat bayi agar ibu dapat memijat dengan teknik yang tepat. Penelitian ini bertujuan untuk mengetahui hubungan antara karakteristik ibu yang memiliki bayi usia 0-24 bulan dengan pengetahuan ibu tentang pijat bayi di Puskesmas Ciruas Tahun 2018. Jenis Penelitian ini adalah deskriptif analitik dengan rancangan penelitian cross sectional. Populasi penelitian ini adalah ibu yang mempunyai bayi usia 0 - 24 bulan berjumlah 152 orang. Sampel sebanyak 60 orang, sampel diambil dengan cara Quota sampling dari 7 posyandu di Puskesmas Ciruas. Pengumpulan data menggunakan kuesioner dan wawancara langsung. Hasil penelitian menunjukkan sebanyak 55\% pengetahuan kurang. Terdapat hubungan yang signifikan antara umur, paritas, pendidikan dan pekerjaan ibu dengan pengetahuan ibu tentang pijat bayi. Dapat disimpulkan bahwa karakteristik ibu berhubungan dengan pengetahuan ibu tentang pijat bayi.
\end{abstract}

Kata Kunci: Karakteristik Ibu, Pengetahuan, Pijat Bayi

\section{Relationship Characteristics Of M others Who Have Babies Aged 0-24 M onths With Knowledge Of Baby Massage}

\begin{abstract}
Baby massage as a form of touch language has a positive effect on the growth and development of babies. Baby massage can increase levels of the enzyme absorption of gastric and insulin so that food absorption is better, causing babies to starve more quickly, suckle more often and increase milk production. Mothers who have babies need knowledge about baby massage so that mothers can massage with the right techniques. This study aims to determine the correlation between the characteristics of mothers who have babies aged 0-24 months with the mother's knowledge of infant massage at Ciruas Health Center in 2018. This type of research is analytic descriptive with a crosssectional research design. The population of this research is 152 mothers who have babies aged 24-24 months. A sample of 60 people, the sample was taken by means of Quota sampling from 7 posyandu at the Puskesmas Ciruas. Data collection using questionnaires and direct interviews. The results showed as much as $55 \%$ less knowledge. There is a significant relationship between age, parity, education, and occupation of mothers with the mother's knowledge of baby massage. It can be concluded that the mother's characteristics are related to the mother's knowledge about baby massage.
\end{abstract}

Keywords: Babies massage, Knowledge, Mothers caracteristic 
Faletehan Health Journal, 7 (1) (2020) 42-47

www. journal.Ippm-stikesfa.ac.id/ojs/index.php/FHJ

ISSN 2088-673X | 2597-8667

\section{Pendahuluan}

Indikator yang digunakan untuk mengukur derajat kesehatan masyarakat adalah angka kematian, angka kesakitan dan status gizi. Angka kematian bayi merupakan salah satu indikator sosial yang sangat penting untuk mengukur keberhasilan program kesehatan ibu dan anak. Secara garis besar penyebab kematian bayi terdiri dari 2 hal yaitu endogen (neonatal) dan kematian eksogen (post neonatal). (Profil Dinas Kesehatan Kabupaten Serang, 2016). Kematian Neonatal adalah kematian bayi yang terjadi pada bulan pertama setelah dilahirkan umumnya disebabkan oleh faktor-faktor bawaan lahir, sedangkan kematian post neonatal adalah kematian bayi yang terjadi setelah usia satu bulan sampai menjelang usia satu tahun yang disebabkan faktor pengaruh lingkungan luar (Profil Dinas Kesehatan Kabupaten Serang, 2016).

Penilaian lain untuk derajat kesehatan bayi selain kematian adalah morbiditas. Morbiditas (kesakitan) merupakan suatu penyimpangan dari status sehat dan sejahtera, atau keberadaan suatu kondisi sakit. Morbiditas dapat diturunkan dengan melakukan pemijatan pada bayi yang bermanfaat untuk meningkatkan berat badan bayi, meningkatkan pertumbuhan, meningkatkan daya tahan tubuh, meningkatkan produksi ASI, memperbaiki sirkulasi darah dan pernapasan dan mengurangi kembung serta kolik yang diakibatkan karna mengkonsumsi susu formula. (Profil Dinas Kesehatan Kabupaten Serang, 2016; Roesli, 2010).

Pijat bayi adalah perawatan kesehatan pada bayi dengan terapi sentuh dengan teknik tertentu. Banyak penelitian menunjukkan bahwa pemijatan pada bayi memberikan manfaat sangat besar pada perkembangan bayi, baik secara fisik maupun secara emosional. Pijat bayi dapat digunakan untuk menurunkan angka kesakitan pada bayi dan mengoptimalkan tumbuh kembang bayi (Enidya, 2012; Maharani, 2009; Roesli, 2010). Pijat bayi adalah pemijatan yang dilakukan lebih mendekati usapan-usapan halus atau ransangan raba (taktil) yang dilakukan dipermukaan kulit, manipulasi terhadap jaringan atau organ tubuh bertujuan untuk menghasilkan efek terhadap syaraf otot, dan sistem pernafasan serta memperlancar sirkulasi darah. (Maharani, 2009; Roesli, 2010). Pijat pada dasarnya akan menciptkan bonding attachment dan selain itu pijat bayi dapat meningkatkan berat badan bayi (Enidya, 2012; Maharani, 2009; Roesli, 2010).

Hasil studi pendahuluan yang dilakukan oleh peneliti kepada 10 orang ibu yang memiliki bayi usia 0-24 bulan diberikan kuesioner pengetahuan tentang pijat bayi, didapatkan hasil terdapat 9 orang ibu dengan pengetahuan kurang tentang pijat bayi. Dari latar belakang diatas, maka tujuan penelitian ini adalah untuk mengetahui hubungan karakteristik ibu yang memiliki bayi usia $0-24$ bulan dengan pengetahuan tentang pijat bayi di Puskesmas Ciruas Tahun 2018.

\section{Metode Penelitian}

Penelitian ini menggunakan desain cross sectional (potong silang) melihat hubungan antara variabel dependen (pengetahuan tentang pijat bayi) dan variabel independen (karakteristik ibu) secara bersamaan (Chandra, 2008). Penelitian dilaksanakan di Puskesmas Ciruas pada bulan Februari-Maret 2018. Populasi penelitian ini adalah ibu yang mempunyai bayi usia 0 - 24 bulan sebanyak 152 orang dengan jumlah sampel sebanyak 60 orang. Teknik pengambilan sampel yang digunakan quota sampling perwakilan dari 7 posyandu Puskesmas Ciruas dengan proposi sampel tiap posyandu misalnya posyandu A jumlah bayi $23(23 / 152 * 60)=9$ bayi dan seterusnya hingga 7 posyandu kemudian dijumlahkan sebanyak 60 orang. Instrumen penelitian ini menggunakan kuesioner yang dibuat sendiri untuk mengumpulkan data karakteristik ibu dan pengetahuan. Kuesioner beisi 10 pertanyaan pengetahuan tentang pijat bayi. Uji ini dilakukan pada orang yang karakteristiknya hampir sama dengan sampel penelitian. Sepuluh pertanyaan telah dilakukan uji validitas dan reabilitas dengan hasil dari uji validitas menunjukkan bahwa semua item pertanyaan pada kuesioner pengetahuan adalah valid yaitu nilai korelasi setiap item pertanyaan > r table $(0.361)$ dan reliabel. Analisis data menggunakan analisis univariat dan bivariat menggunakan uji Chi Square (Nursalam, 2008; Priyo, 2006).

\section{Hasil dan Pembahasan Karakteristik Responden}

Berdasarkan tabel 1 sebanyak $50 \%$ Ibu berumur 20-35 tahun dan >35 tahun, sebanyak $73,3 \%$ Ibu mempunyai paritas 2-4, sebanyak 
$71.7 \%$ Ibu tidakn bekerja, sebanyak $60 \%$ mempunyai pendidikan Menengah.

Hubungan antara Umur, Paritas, Pendidikan dan Pekerjaan Ibu dengan Pengetahuan tentang Pijat Bayi

Berdasarkan tabel 2 menunjukan data bahwa sebagian besar ibu berumur antara 20-34 tahun dengan pengetahuan kurang sebanyak 21 orang (70\%), sebagian besar paritas ibu 2-4 dengan pengetahuan kurang sebanyak 33 orang $(75 \%)$, sebagian besar pendidikan ibu pendidikan menengah dengan pengetahuan kurang sebanyak 33 orang (91.7\%), sebagian besar ibu tidak bekerja dengan pengetahuan kurang sebanyak 33 orang $(76.7 \%)$.

Dari hasil analisis bivariat dengan menggunakan uji Chi-square diperoleh secara statistik pada $\alpha 5 \%$ ada hubungan yang signifikan antara nilai umur (nilai $\mathrm{P}=0,038$ ), paritas (nilai $\mathrm{P}$ $=0,000$ ), pendidikan (nilai $\mathrm{P}=0,000$ ), pekerjaan (nilai $\mathrm{P}=0,000$ ) pekerjaan ibu dengan pengetahuan tentang pijat bayi di Puskesmas Ciruas Tahun 2018.
Tabel 1. Distribusi Frekuensi Umur, Paritas, Pekerjaan, Pendidikan dan Pengetahuan Ibu Yang Memiliki Bayi Usia 0 - 24 Bulan.

\begin{tabular}{lcc}
\hline \multicolumn{1}{c}{ Variabel } & n & \% \\
\hline Umur & & \\
$\quad<20$ Tahun & - & - \\
20-35 Tahun & 30 & 50 \\
$\quad$ 35 Tahun & 30 & 50 \\
\hline Paritas & & \\
$\quad 1$ & 12 & 20 \\
$2-4$ & 44 & 73,3 \\
$\quad>4$ & 4 & 6,7 \\
\hline Pekerjaan & & \\
$\quad$ Bekerja & 17 & 28,3 \\
$\quad$ Tidak Bekerja & 43 & 71,7 \\
\hline Pendidikan & & \\
$\quad$ Pendidikan Rendah & 17 & 28,3 \\
$\quad$ Pendidikan Menengah & 36 & 60 \\
$\quad$ Pendidikan Tinggi & 7 & 11,7 \\
\hline Pengetahuan & & \\
$\quad$ Baik & 27 & 45 \\
$\quad$ Kurang & 33 & 55 \\
\hline Jumlah & 60 & 100 \\
\hline
\end{tabular}

Tabel 2. Hubungan antara Umur, Paritas, Pendidikan dan Pekerjaan Ibu dengan Pengetahuan tentang Pijat Bayi

\begin{tabular}{|c|c|c|c|c|c|c|}
\hline \multirow{3}{*}{ Variabel } & \multicolumn{4}{|c|}{ Pengetahuan } & \multirow{3}{*}{ Jumlah } & \multirow{3}{*}{ Nilai $\mathbf{P}$} \\
\hline & \multicolumn{2}{|c|}{ Baik } & \multicolumn{2}{|c|}{ Kurang } & & \\
\hline & $\mathbf{N}$ & $\%$ & $\mathbf{N}$ & $\%$ & & \\
\hline \multicolumn{7}{|l|}{ Umur } \\
\hline 20-34 tahun & 9 & 30 & 21 & 70 & 30 & 0,038 \\
\hline$>35$ tahun & 18 & 60 & 12 & 40 & 30 & \\
\hline \multicolumn{7}{|l|}{ Paritas } \\
\hline 1 & 5 & 41.7 & 7 & 58.3 & 12 & 0000 \\
\hline $2-4$ & 11 & 25 & 33 & 75 & 44 & 0,000 \\
\hline$>4$ & 4 & 100 & 0 & 0 & 4 & \\
\hline \multicolumn{7}{|l|}{ Pendidikan } \\
\hline Pendidikan Rendah & 5 & 29.5 & 12 & 70.5 & 17 & \\
\hline Pendidikan Menengah & 3 & 8.3 & 33 & 91.7 & 36 & 0,000 \\
\hline Pendidikan Tinggi & 3 & 42.9 & 4 & 57.1 & 7 & \\
\hline \multicolumn{7}{|l|}{ Pekerjaan } \\
\hline Bekerja & 10 & 58.8 & 7 & 41.2 & 17 & 0,000 \\
\hline Tidak Bekerja & 10 & 23.3 & 33 & 76.7 & 43 & \\
\hline
\end{tabular}


Faletehan Health Journal, 7 (1) (2020) 42-47

www. journal.Ippm-stikesfa.ac.id/ojs/index.php/FHJ

ISSN 2088-673X | 2597-8667

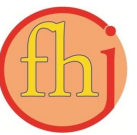

\section{Pengetahuan}

Hasil penelitian ini menunjukan sebagian besar Ibu memiliki pengetahuan kurang tentang pijat bayi. Menurut Notoatmodjo, pengetahuan merupakan hasil dari tahu, dan ini terjadi setelah orang melakukan penginderaan terhadap suatu objek tertentu. Penginderaan terjadi melalui panca indera manusia, yakni indera penglihatan, pendengaran, penciuman, rasa dan raba.(Notoatmodjo, 2010b) Pengetahuan manusia Sebagian besar diperoleh melalui mata dan telinga. Faktor yang mempengaruhi pengetahuan ini meliputi : pendidikan, pekerjaan, usia, minat, pengalaman, kebudayaan sekitar, dan informasi. (Notoatmodjo, 2010b). Pengetahuan tentang pijat bayi adalah hasil tahu dan kesan dalam perawatan kesehatan bayi dengan menggunakan tehnik atau gerakan pijat pada bayi untuk merangsang pertumbuhan dan perkembangan bayi secara optimal.

Pengetahuan tentang pijat bayi yang perlu diketahui ibu sepeti pengertian pijat bayi, kapan waktunya memijat bayi, siapa saja yang boleh melakukan pijat bayi, apa yang perlu dipersiapkan ketika akan memijat bayi dan bagaimana langkahlangkah melakukan pijat bayi (Roesli, 2010). Semakin tinggi pengetahuan seseorang tentang pijat bayi akan meningkatkan kemauan dalam melakukan pijat bayi. Bertambahnya pengalaman memijat bayi akan menambah keterampilan seseorang pijat bayi (Santoso, 2017).

Faktor-faktor Yang Mempengaruhi Pengetahuan Menurut (Mubarak, 2009) yaitu:1) Pendidikan, bimbingan yang diberikan seseorang kepada orang lain terhadap suatu hal agar dapat memahami. Semakin tinggi pendidikan, maka semakin mudah pula dalam menerima informasi. Sebaliknya, jika pendidikan rendah, maka akan menghambat perkembangan pengetahuan seseorang terhadap penerimaan informasi dan nilai-nilai yang baru diperkenalkan. 2) Pekerjaan, dapat menjadikan seseorang memperoleh pengalaman dan pengetahuan baik secara langsung maupun secara tidak langsung. 3) Usia, dengan bertambahnya usia seseorang, maka akan terjadi perubahan pada aspek fisik dan psikologis (mental). 4) Minat, adalah suatu keinginan terhadap sesuatu. Minat membuat seseorang untuk mencoba dan menekuni suatu hal dan akhirnya mendapat pengetahuan yang lebih mendalam.5) Pengalaman, adalah suatu peristiwa yang dialami seseorang dalam berinteraksi dengan lingkungannya. 6) Kebudayaan lingkungan sekitar, mempunyai pengaruh besar terhadap pembentukan sikap pribadi seseorang.

\section{Umur Ibu dengan Pengetahuan Pijat Bayi}

Hasil penelitian sejalan dengan hasil penelitian Nora Safrina (2013) yang menyebutkan bahwa terdapat hubungan antara usia ibu dengan pengetahuan ibu tentang pijat bayi (Safrina, 2013). Teori sebelumnya menyatakan bahwa usia mempengaruhi terhadap daya tangkap dan pola pikir seseorang (Notoatmodjo, 2010b). Semakin bertambah usia akan semakin berkembang pula daya tangkap dan pola pikirnya, sehingga pada saat diberikan pengetahuan tentang pijat bayi melalui penyuluhan tentang pijat bayi lebih mudah untuk memahaminya. Apalagi jika penyuluhannya ditambah dengan diberikan leaftlet tentang pijat bayi maka ibu akan dibaca kembali dengan seksama sehingga pengetahuan ibu tentang pijat bayi akan meningkat (Hidayat, 2007). Dari uraian ini maka dapat disimpulkan bahwa bertambahnya umur seseorang dapat berpengaruh pada pertambahan pengetahuan yang diperolehnya, akan tetapi pada umur-umur tertentu atau menjelang usia lanjut kemampuan penerimaan atau mengingat suatu pengetahuan akan berkurang (Meliono, 2007). penelitian ini menunjukkan bahwa umur ibu berhubungan signifikan (nilai $P=0.038$ ) dengan pengetahuan ibu tentang pijat bayi. Pada penelitian ini umur ibu 20-34 tahun dengan pengetahuan. Kurangnya pengetahuan tentang pijat bayi disebabkan karena kurangnya informasi dan penyuluhan tentang pentingnya pijat bayi.

\section{Paritas Ibu dengan Pengetahuan Pijat Bayi}

Hasil penelitian ini menunjukan bahwa terdapat hubungan antara paritas dengan pengetahuan ibu tentang pijat bayi. Hasil penelitian ini sejalan dengan teori Notoatmodjo (2007) yang menyatakan bahwa pengalaman merupakan sumber pengetahuan atau suatu cara untuk memperoleh kebenaran dan pengetahuan. Pengalaman menjadi salah satu faktor meningkatnya pengetahuan seseorang. Orang yang memiliki pengalaman merawat banyak anak akan mempunyai pengetahuan yang baik bila dibandingkan dengan orang yang mengalami merawat satu anak. Jika ibu sering melakukan 
pijat bayi pada anak pertamanya maka ibu akan mahir pijat bayi pada anak keduanya. Hasil penelitian ini tidak sejalan dengan hasil penelitian sebelumnya yang menyatakan bahwa tinggi rendahnya keterampilan memijat bayi seseorang tidak selalu dipengaruhi oleh paritas yaitu primipara ataupun multipara Lestari (2015). Hal ini disebabkan semakin berkembangnya ilmu pengetahuan dan teknologi, sehingga seorang ibu baik primipara ataupun multipara sama-sama dapat meningkatkan pengetahuan dan keterampilan yang dalam hal ini adalah keterampilan memijat bayi. Berdasarkan penjelasan diatas menunjukkan bahwa ibu yang memiliki anak 2-4 memiliki pengalaman yang baik tentang perawatan bayi, tetapi tidak tentang pijat bayi, karena pengetahuan ibu tentang pijat bayi kurang sehingga ibu tidak memiliki pengalaman tentang pijat bayi. Semakin tinggi pengetahuan dan pengalaman seseorang tentang suatu ilmu maka semakin baik pula pengetahuannya tentang ilmu tersebut. (Notoatmodjo, 2010b)

\section{Pendidikan dengan Pengetahuan Pijat Bayi}

Dalam peneitian ini pendidikan ibu terbagi menjadi 3 kategori yaitu Rendah (SD-SMP) sebanyak 17 orang (28.3\%), Menengah (SMA) sebanyak 36 orang (60\%), Tinggi (PT) sebanyak 7 orang $(11.7 \%)$. Pada penelitian ini sebagian besar pendidikan ibu menengah dengan pengetahuan kurang sebanyak 33 orang (91.7\%) dan terdapat hubungan antara pendidikan dengan pengetahuan ibu tentang pijat bayi. Hasil penelitian ini sejalan dengan penelitian sebelumnya yang menunjukkan bahwa ada korelasi antara pendidikan dengan pijat bayi (Nureani, 2015). Pendidikan adalah suatu proses dimana pengalaman atau informasi diperoleh sebagai hasil dari proses belajar (Notoatmodjo, 2010b). Pendidikan, bimbingan yang diberikan seseorang kepada orang lain terhadap suatu hal agar dapat memahami. Jika ibu diberikan pendidikan dan pengetahuan tentang pijat bayi maka pemahaman ibu tentang pijat bayi akan baik. Pada penelitian ini pendidikan ibu ratarata berada pada pendidikan menengah, pada jenjang pendidikan tersebut secara teori ibu mudah dalam menerima informasi. Sebaliknya, jika tingkat pendidikan yang rendah, maka akan menghambat seseorang terhadap penerimaan informasi (Mubarak, 2009). Pendidikan kesehatan tentang pijat bayi adalah suatu upaya atau kegiatan untuk meningkatkan pengetahuan ibu tentang pijat bayi (Notoatmodjo, 2007). Pendidikan kesehatan adalah semua kegiatan untuk memberikan dan atau meningkatkan pengetahuan, sikap, dan praktek baik individu, kelompok atau masyarakat dalam memelihara dan meningkatkan kesehatan mereka sendiri dalam hal ini khususnya tentang pijat bayi (Mubarak, 2009; Notoatmodjo, 2010a). Semakin tinggi pendidikan ibu maka semakin baik pengetahuan ibu. Semakin sering ibu diberikan pendidikan tentang pijat bayi maka semakin baik pengetahuan ibu tentang pijat bayi, begitu juga sebaliknya. Tingkat pendidikan ibu yang sebagian besar hanya kategori menengah keatas tentunya membuat akses informasi yang diterima ibu juga terbatas, yang berakibat pada rendahnya pengetahuan ibu tentang pijat bayi.

\section{Pekerjaan dengan Pengetahuan Pijat Bayi}

Pekerjaan adalah kegiatan yang dilakukan dan mendapat penghasilan atas kegiatan tersebut, dalam penelitian ini pekerjaan dibagi menjadi 2 kategori yaitu bekerja dan tidak bekerja. Pada penelitian ini sebagian besar ibu tidak bekerja dengan pengetahuan kurang sebanyak 33 orang (76.7\%). Hasil penelitian ini sejalan dengan penelitian yang dilakukan (Widyawati, 2012) yang menunjukkan bahwa ada hubungan antara pekerjaan ibu dengan pengetahuan tentang pijat bayi. Penelitian ini juga sejalan dengan teori yang menyatakan bahwa lingkungan pekerjaan dapat menjadikan seseorang memperoleh pengalaman dan pengetahuan baik secara langsung maupun secara tidak langsung. Jika di tempat kerja ibu mendapatkan pendidikan kesehatan tentang pijat bayi maka pengetahuan ibu tentang pijat bayi akan baik. Karena secara tidak langsung pekerjaan turut andil dalam mempengaruhi tingkat pengetahuan seseorang, pekerjaan berhubungan erat dengan faktor interaksi sosial, kebudayaan, dan proses pertukaran informasi. Khususnya pengetahuan dan informasi tentang pijat bayi ditempat kerja (Ningsih, 2012; Notoatmodjo, 2010b). Peningkatan pengetahuan ibu tentang pijat bayi bisa diadapatkan dari teman kerja pada saat interaksi sosial atau diadakan program peningkatan kesehatan tenaga kerja oleh perusahaan dalam bentuk penyuluhan kesehatan bekerjasama dengan instansi kesehatan terdekat. Ibu yang bekerja akan memiliki pengetahuan yang baik karena banyak memperoleh informasi dari berbagai sumber seperti lingkungan, teman kerja, 
Faletehan Health Journal, 7 (1) (2020) 42-47

www. journal.Ippm-stikesfa.ac.id/ojs/index.php/FHJ

ISSN 2088-673X | 2597-8667

media massa dan lain-lain. Dalam proses interaksi sosial tentunya sering terjadi pertukaran informasi, khususnya jika ada teman kerja yang mengetahui tentang pijat bayi maka teman yang lain akan mengetahui juga, sebaliknya jika ibu tidak bekerja pengetahuannya akan terbatas tentang kesehatan apapun khususnya pijat bayi.

\section{Simpulan}

Hasil penelitian menyimpulkan bahwa sebagian besar ibu yang memiliki bayi usia 0-24 bulan mempunyai pengetahuan kurang dan terdapat hubungan yang signifikan antara umur, paritas, pendidikan dan pekerjaan dengan pengetahuan ibu tentang pijat bayi.

\section{Referensi}

Chandra, B. (2008). Metodologi Penelitian Kesehatan (Cetakan Pe). Jakarta: EGC.

Enidya, S. (2012). Buku Pintar Pijat Bayi untuk Tumbuh Kembang Optimal Sehat dan Cerdas. Yogyakarta: Pinang Merah.

Hidayat. (2007). Metodologi Penelitian Keperawatan Dan Teknik Analisa Data. Jakarta: Salemba Medika.

Maharani, S. (2009). Pijat dan Senam Sehat Untuk bayi. Yogyakarta: Kata Hati.

Meliono. (2007). Pengetahuan. In: MPKT Modul 1. Jakarta: FEUI.

Mubarak. (2009). Ilmu Keperawatan Komunitas Pengantar Dan Teori. Jakarta: Salemba Medika.

Ningsih. (2012). Pengaruh Penyuluhan Kesehatan Terhadap Keterampilan Pijat Anak oleh Ibu di Dusun Karanganyar Gadingharjo Sanden Bantul Yogyakarta.
Notoatmodjo, S. (2010a). Promosi Kesehatan: Teori dan Aplikasi. Jakarta: Rineka Cipta.

Notoatmodjo, S. (2010b). Ilmu Perilaku Kesehatan. Jakarta: Rineka Cipta.

Nureani. (2015). Pengaruh Pelatihan Pijat Bayi Terhadap Keterampilan Ibu Melakukan Pijat Bayi Di Posyandu Nusa Indah Dusun Pranti Pundong Bantul Yogyakarta.

Nursalam, dkk. (2008). Konsep dan Penerapan Metodelogi Riset Keperawatan. Jakarta: Info Medika.

Priyo, sutanto. (2006). Analisis Data. Jakarta: FKM UI.

Profil Dinas Kesehatan Kabupaten Serang. (2016). Serang.

Roesli, U. (2010). Pedoman Pijat Bayi Prematur dan Bayi Usia 0 -3 Bulan. Jakarta: Trubus Agriwidya.

Safrina, N. (2013). Faktor - Faktor Yang Mempengaruhi Pengetahuan Ibu Tentang Pijat Bayi Di BPS Jauniwati Indrapuri Kabupaten Aceh Besar. 1-8.

Santoso, T. (2017). Kepuasan Ibu dalam Melakukan Massage Bayi di Wilayah Puskesmas Buaran Kabupaten Pekalongan. 1(3), 133-139.

Widyawati. (2012). Hubungan Karakteristik Ibu dengan Pengetahuan tentang Pijat Bayi di wilayah Kerja Puskesmas Gribig. 